\title{
A Global Scale Estimate of Novel Coronavirus (COVID-19) Cases Using Extreme Value Distributions
}

\author{
M. Aadhityaa ${ }^{1}$, K. S. Kasiviswanathan ${ }^{2 *}$, Idhayachandhiran Ilampooranan ${ }^{2}$,
}

B. Soundharajan', M. Balamurugan ${ }^{3}$, Jianxun $\mathrm{He}^{4}$

5

${ }^{2}$ Department of Water Resources Development and Management, Indian Institute of Technology

7 Roorkee, India

$8{ }^{3}$ Department of Civil and Environmental Engineering, National University of Singapore,

$9 \quad$ Singapore

$10{ }^{4}$ Department of Civil Engineering, Schulich School of Engineering, University of Calgary,

11 Calgary, Canada

12

$13 *$ k.kasiviswanathan@wr.iitr.ac.in (KSK)

\section{Abstract}

15 The COVID-19 pandemic has created a global crisis and the governments are fighting rigorously

16 to control the spread by imposing intervention measures and increasing the medical facilities. In

17 order to tackle the crisis effectively we need to know the trajectories of number of the people

18 infected (i.e. confirmed cases). Such information is crucial to government agencies for

19 developing effective preparedness plans and strategies. We used a statistical modeling approach

20 - extreme value distributions (EVDs) for projecting the future confirmed cases on a global scale.

21 Using the 69 days data (from January 22, 2020 to March 30, 2020), the EVDs model predicted

22 the number of confirmed cases from March 31, 2020 to April 9, 2020 (validation period) with an 
medRxiv preprint doi: https://doi.org/10.1101/2020.04.17.20069500; this version posted April 22, 2020. The copyright holder for this preprint (which was not certified by peer review) is the author/funder, who has granted medRxiv a license to display the preprint in perpetuity.

It is made available under a CC-BY-NC-ND 4.0 International license .

23 absolute percentage error $<15 \%$ and then projected the number of confirmed cases until the end

24 of June 2020. Also, we have quantified the uncertainty in the future projections due to the delay

25 in reporting of the confirmed cases on a global scale. Based on the projections, we found that

26 total confirmed cases would reach around 11.4 million globally by the end of June 2020.The

27 USA may have 2.9 million number of confirmed cases followed by Spain-1.52 million and Italy-

$28 \quad 1.28$ million.

Keywords: COVID-19, Statistical modeling; Extreme value distributions; Future projection; Confirmed cases.

\section{Introduction}

33 The first case of respiratory disease, pneumonia, with symptoms similar to the severe acute respiratory syndrome coronavirus (SARS-CoV) was reported in Wuhan City, China in December 2019 [1]. A novel strain of severe acute respiratory syndrome coronavirus 2 (SARS-CoV-2) was confirmed on January 7, 2020 [1, 2]. The novel corona virus (COVID-19), which is the seventh member of the coronavirus family, along with the SARS-CoV and the middle east respiratory syndrome coronavirus (MERS-CoV) spread from animals to humans [2]. Since the reporting of the zero-patient in December 2019, COVID-19 has spread dramatically worldwide and the World Health Organization (WHO) has declared the outbreak as Public Health Emergency of International Concern (PHEIC) on January 30, 2020 [2]. As of April 9, 2020, globally the total number of confirmed, recovered, and mortality cases were 1,595,350, 353,975 and 95,455 respectively [3]. The reported cases globally are drastically increasing from 4,219/day in

44 February 2020 to 50,784/day in early April 2020. The trajectory of the infection spread during 45 the coming days is important information in order to plan, prepare, and scale up the intervention 
medRxiv preprint doi: https://doi.org/10.1101/2020.04.17.20069500; this version posted April 22, 2020. The copyright holder for this preprint (which was not certified by peer review) is the author/funder, who has granted medRxiv a license to display the preprint in perpetuity. It is made available under a CC-BY-NC-ND 4.0 International license .

measures including the medical facilities to meet the increased influx of patients and other governing policies to control the transmission.

To date (as of April 9, 2020), the United States of America (USA) has the highest number of affected cases $(461,437)$, followed by Spain $(153,222)$ and Italy $(143,626)$ [3]. The global casefatality rate (CFR), which is the ratio of the confirmed deaths to the confirmed cases, has increased from $1.37 \%$ on January 19, 2020 to 5.95\% by April 9, 2020 [4]. In contrast, the current CFR of China, Japan, and Iran has either reduced or remained constant when compared to their initial CFR [4]. The global CFR is however increasing continuously due to the different timing of the onset of the pandemic in different countries. Overall, the number of confirmed cases has been explosively increasing with time so far.

Modeling tools have been widely used to predict the COVID-19 spread to help the medical professionals, policymakers, and governing bodies for implementing interventions measures to control the pandemic. Since the onset of COVID-19, studies have used different mathematical and dynamic stochastic transmission models to predict the transmission and intervention impacts that are not readily available due to the absence or lack of the data for extracting the knowledge especially during the early period of the outbreak. These parameters have been either assumed or adopted from previous pandemic studies and consequently the performance of these models has been questioned $[1,11]$.

67 
medRxiv preprint doi: https://doi.org/10.1101/2020.04.17.20069500; this version posted April 22, 2020. The copyright holder for this preprint (which was not certified by peer review) is the author/funder, who has granted medRxiv a license to display the preprint in perpetuity. It is made available under a CC-BY-NC-ND 4.0 International license .

68 To address the above shortcomings of epidemiological models, we proposed a statistical

69 modelling approach, using Extreme Value Distributions (EVD) to describe the evolution of the

70 COVID-19 spread and then to generate the future projections. EVDs are used to fit series of

71 observation mainly to estimate extreme events of future that were not observed in the past.

72 Though application of EVDs are very common in earth sciences to model the unusual events,

73 recently, EVDs are applied in health care sector and shown to produce promising results [12].

74

75 One of the main challenges in simulating and projecting the COVID-19 spread trajectory is the 76 delay in reporting $\left(R_{d}\right)$ which is the lag time between onset of symptoms of the disease and date

77 of reporting [13]. The delay in reporting may vary due to various reasons such as delay in (i)

78 reporting at the hospital, (ii) diagnostics, (iii) reporting the confirmed cases in databases etc.

79 Also, $R_{d}$ imposes high uncertainty in estimating the spread trajectory and thus excluding $R_{d}$ in

80 modeling analysis could lead to unrealistic projections with underestimation in the projected

81 confirmed cases [9]. Very few studies have considered $R_{d}$ in their modeling studies to estimate

82 the transmission dynamics of COVID-19 and reported an average $\mathrm{R}_{\mathrm{d}}$ value of 7.6 days and 6.1

83 days $[9,13]$.

84

85 Therefore, for quantifying the uncertainty in projected cases, we have estimated the fold increase

86 in the confirmed cases due to $\mathrm{R}_{\mathrm{d}}$. Thus, the key contributions of the study are (i) using EVD

87 theory for the projection of COVID-19 cases, (ii) incorporating $R_{d}$ value to estimate the uncertainty in future projections, and (iii) global scale projection of confirmed and death cases. 
medRxiv preprint doi: https://doi.org/10.1101/2020.04.17.20069500; this version posted April 22, 2020. The copyright holder for this preprint (which was not certified by peer review) is the author/funder, who has granted medRxiv a license to display the preprint in perpetuity.

\section{Materials and Method}

91 We collected the daily time series of the number of confirmed and death cases from John

92 Hopkins University Center for Systems Science and Engineering [3] for 177 countries, out of

93 which only 42 countries (refer S1 table) that exceeded 1000 confirmed cases (as on March 30,

94 2020) were considered for the analysis. These 42 countries spread across different continents

95 except Antarctica and accounts for $96.5 \%$ of the total confirmed cases globally as on March 30,

96 2020. We observed that majority of the countries with significant number of confirmed cases are

97 from Europe and Asia followed by North America and South America.

S1 Table: Total number of confirmed COVID 19 cases as on March 30, 2020 (List of

countries short listed based upon a minimum threshold of 1000 confirmed cases)

100

101

Though the number of COVID-19 infected cases were reported even before January 22, 2020 in

102

China especially in the Hubei province, we have not considered that data in the analysis since the

103

COVID-19 outbreak has been contained and extensive research studies have already been

104 conducted $[14,15,16,17]$.

105

Application of extreme value distribution has already been explored to model the mortality and

morbidity rate associated with pneumonia, influenza and cardiovascular diseases in the public

health planning $[12,18]$. Therefore, in this paper, we have explored the applicability of EVDs in

modeling the confirmed COVID-19 cases. Initial statistical analysis of the data revealed that the

critical stage of COVID-19 outbreak largely has no trend in the number of people being infected

111 and therefore the use of EVDs are justified. Among the EVDs, three-parameter distributions such

112 as Generalized Extreme Value (GEV), Generalized Pareto (GP), and Generalized Likelihood 
medRxiv preprint doi: https://doi.org/10.1101/2020.04.17.20069500; this version posted April 22, 2020. The copyright holder for this preprint (which was not certified by peer review) is the author/funder, who has granted medRxiv a license to display the preprint in perpetuity.

It is made available under a CC-BY-NC-ND 4.0 International license .

113 (GL) distributions were explored. The parameters of these distributions mainly define the 114 characteristics such as scale, shape and location of the data being fitted using the EVDs. The tail

115 behaviour of the distribution is described by the shape parameter which is estimated from higher

116 order moments, and precise estimation of shape parameter is often computationally difficult [19,

117 20] and requires suitable moment estimation approaches. Among several methods (i.e. the

118 method of likelihood and the probability weighted moments) for estimating the distribution

119 parameters, the L-moment method has been demonstrated to be more effective in estimating the

120 shape parameters and hence used in this study [21]. As many existing literatures elaborately

121 describe the mathematical description about the extreme value distributions and L-moment

122 methods, the detailed explanations are not provided in this paper.

123

124 Conventionally, EVDs have often been applied in the extreme statistical analysis, which

125 estimates the quantities corresponding to specific return periods or probabilities. In this analysis,

126 the sample data from the population are expected to be independent and identically distributed.

127 In the extreme statistical analysis for natural extreme events such as flooding, earthquake, and

128 tsunami, the annual maximum values are often considered. We observed that in the case of

129 COVID-19, the daily recorded confirmed cases are independent with no trend. Thus, the reported

130 confirmed COVID-19 cases were fitted using the EVDs to project the number of future

131 confirmed cases.

132

133 In general, the reported cases on any given days were lower than the actual infected cases due to

134 various reasons including the delay in the onset of acute symptoms, inefficiency in the testing

135 methods, lack of sufficient testing facilities etc. There is also significant risk of Covid-19 patients 
medRxiv preprint doi: https://doi.org/10.1101/2020.04.17.20069500; this version posted April 22, 2020. The copyright holder for this preprint (which was not certified by peer review) is the author/funder, who has granted medRxiv a license to display the preprint in perpetuity.

It is made available under a CC-BY-NC-ND 4.0 International license .

to be tested positive after initially being tested negative due to the inaccuracies in testing and latent symptoms [22]. However, government authorities mainly health care professionals should be aware and be informed about the discrepancy between the reported and actual infected cases to effectively tackle the current COVID-19 situations. Thus, we also estimated the fold increase in the number of confirmed cases due to the delay in reporting. To account the effect of the delay in reporting on the confirmed cases, we considered a Reporting delay $\left(\mathrm{R}_{\mathrm{d}}\right)$ of 1 to 7 days and have proposed a simple statistical lagging approach to estimate the fold increase in the number of

confirmed cases. For this analysis, the ratio $\left[\frac{C_{t}}{C_{t-l a g}}\right]$ of confirmed cases on the current date $C_{t}$ to the previously lagged date $C_{t-l a g}$ were computed using the complete data having n data points. The mean value of the fold increase was estimated from the ratios (For example, lag of 5 days will have $n-5$ number of ratios) for each $R_{d}$. Furthermore, the estimate of the fold increase (with its uncertainty) was coupled with the future projection of the confirmed cases for quantifying associated uncertainty in the projection. Note that other than $R_{d}$, no other sources of uncertainty such as incubation period, communal spread, the effects of lockdown or other containment strategies, healthcare capacity, etc. were included in our study.

\section{Results and discussion}

\section{Statistical tests and model performance}

The daily number of the confirmed cases from the selected 42 countries were computed from the reported cumulative data. These data were further processed with the modified Mann-Kendall test to check for the presence of non-parametric trend and we found that there is no trend in the entire dataset. This proves that the data are statistically independent and identically distributed 
medRxiv preprint doi: https://doi.org/10.1101/2020.04.17.20069500; this version posted April 22, 2020. The copyright holder for this preprint (which was not certified by peer review) is the author/funder, who has granted medRxiv a license to display the preprint in perpetuity.

It is made available under a CC-BY-NC-ND 4.0 International license .

157 during the critical stage of pandemic situation. Hence, we applied extreme value distribution to

158 model the available data as well as to project the COVID-19 cases.

160 As mentioned earlier, three different EVDs were explored to fit the datasets for the numbers of 161 confirmed cases. The root mean squared error (RMSE) computed for each distribution against 162 observation for all datasets are plotted in the boxplot (Fig 1). It is evident from Fig 1 that all the 163 three distributions (GEV, GP and GL) performed equivalently. Furthermore, the fitting 164 performance was slightly improved when using the GP distribution compared to GEV and GL 165 distributions and in particular the GP performed consistently well across all the datasets. In 166 addition, large variations in the estimated distribution parameters (i.e., location, scale, and shape

167 parameters) were identified. The results of parameter variations of GP have been shown in S2 168 Fig. These variations would reflect the variations in the statistical characteristics of the datasets 169 of different countries. As these models are data specific with parameters not having direct 170 physical meaning, it is hard to link the behaviour of parameters with the modelled variables.

171 Since we observed better performance and lower RMSE using GP distribution, in this study, we 172 are projecting the estimates of confirmed cases for selected countries using the GP models.

173 S2 Fig: Estimated parameters of the GP Models 


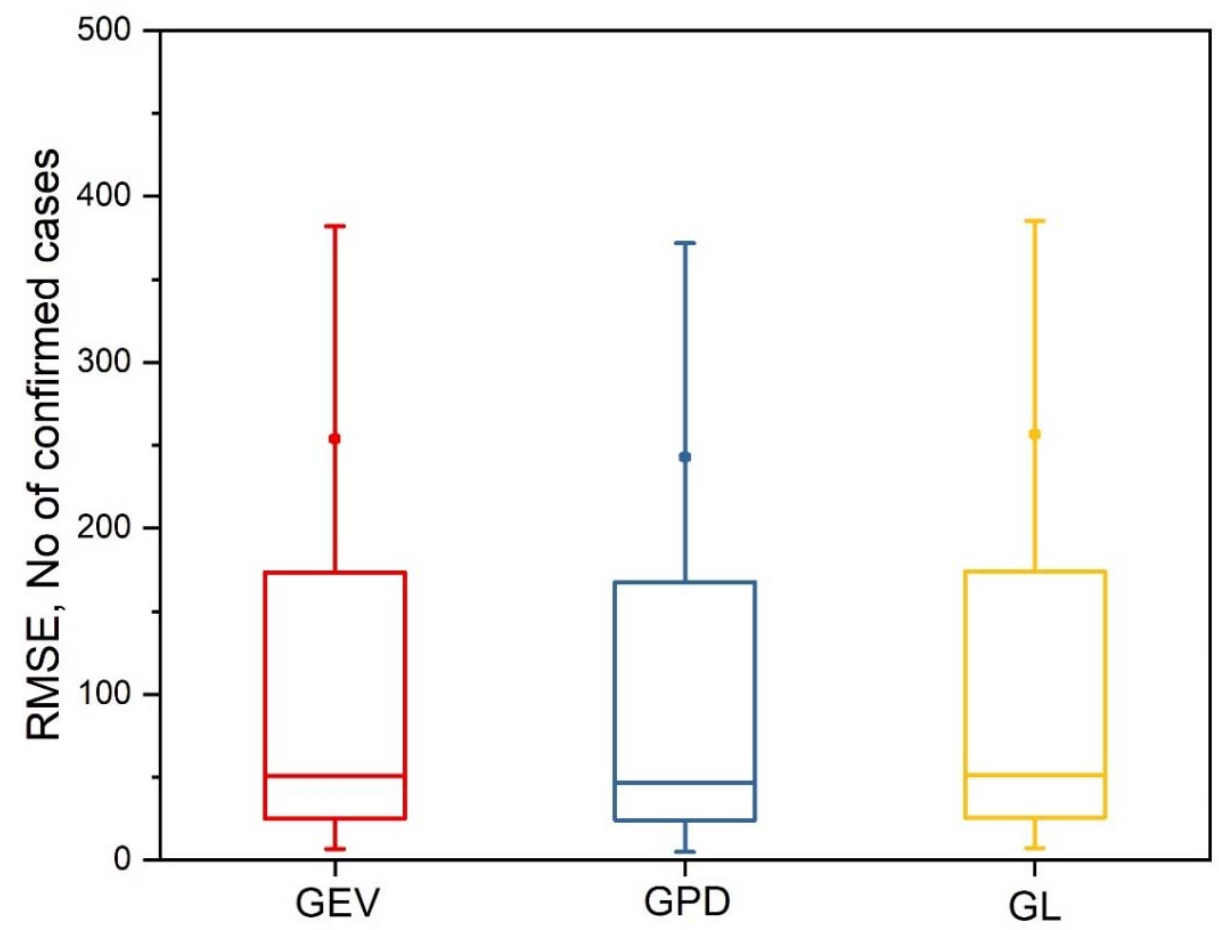

Fig 1. Performance of three different Extreme value probability distributions for fitting the confirmed cases of all 42 countries

Although the outbreak had started in the beginning of January 2020 in Wuhan, China, majority demonstrates the different timing of the onset of the spread in different countries. However, we considered same period (January 22, 2020 to March 30, 2020) for the model calibration which in turn resulted a uniform data length of all the selected countries for estimating the parameters of distribution.

The model performance has been validated by comparing the model's projections and the 187 confirmed cases observed for the selected countries for the period of 10 days (March 31 - April 9, 2020). The mean and standard deviation of the resulting percentage error (i.e. ratio of difference between observed minus projected to observed cases) has been shown in Fig 2. Please 
medRxiv preprint doi: https://doi.org/10.1101/2020.04.17.20069500; this version posted April 22, 2020. The copyright holder for this preprint (which was not certified by peer review) is the author/funder, who has granted medRxiv a license to display the preprint in perpetuity.

It is made available under a CC-BY-NC-ND 4.0 International license .

190

191

note that the positive and negative value of mean of the percentage error indicates under and overestimate of the projected value, respectively. From Fig 2, it is evident that the mean and standard deviation of the percentage error are within the $\pm 5 \%$ and $\pm 10 \%$ respectively for most of the countries, and the overall performance of model is quite satisfactory for majority of the cases except few. The poor performance of model for few countries, for example Germany, Australia, and Iran, might be due to high variation in the infected cases. As more data is available in future, more critical validation of these models can be performed to bring additional insights on the reliability of the model projection.

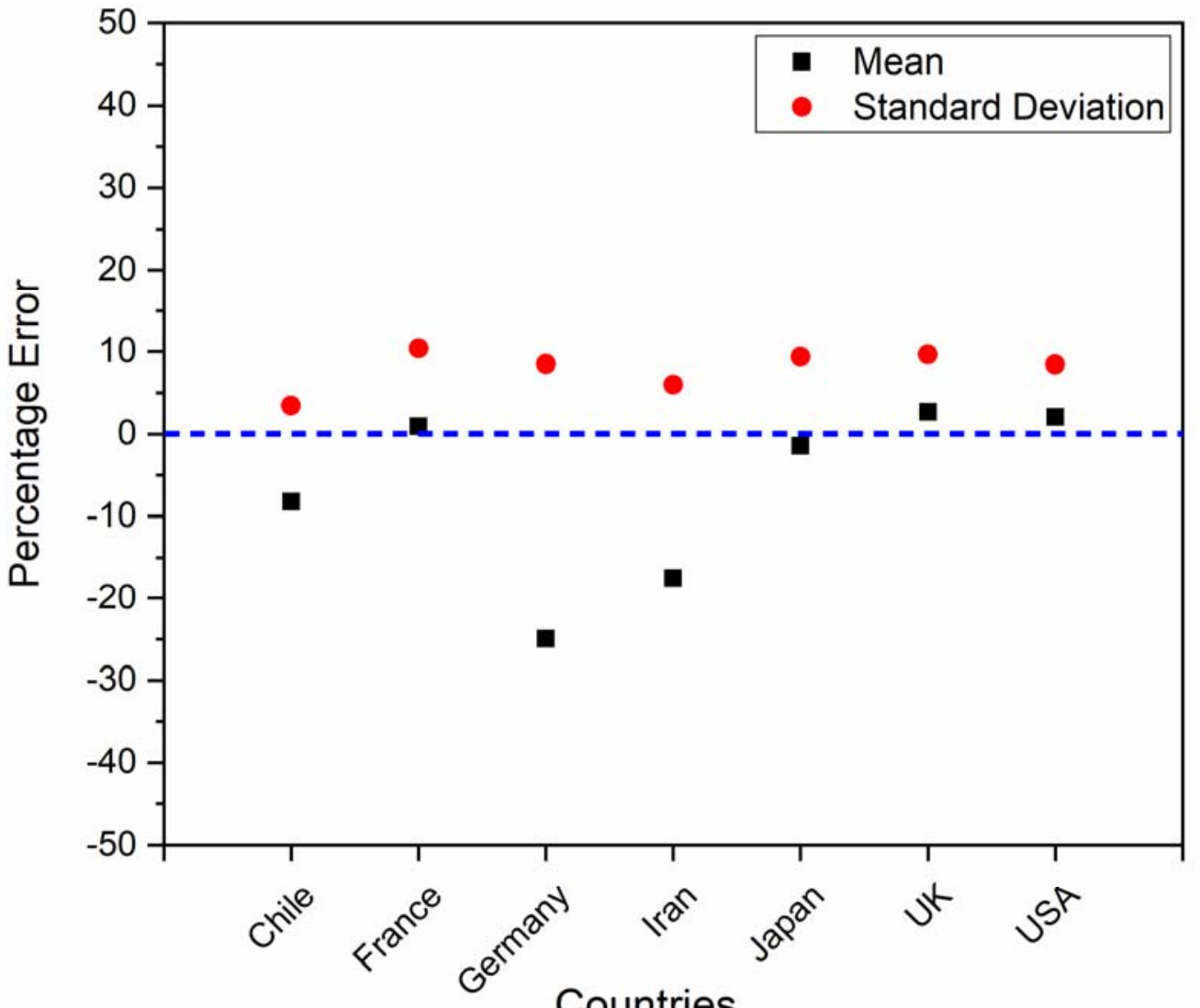

Fig 2 Percentage error in the projected confirmed cases for the validation period from March 31, 2020 to April 09, 2020 
medRxiv preprint doi: https://doi.org/10.1101/2020.04.17.20069500; this version posted April 22, 2020. The copyright holder for this preprint (which was not certified by peer review) is the author/funder, who has granted medRxiv a license to display the preprint in perpetuity.

It is made available under a CC-BY-NC-ND 4.0 International license .

202

203

204

205

206

207

208

209

210

\section{Projection of COVID-19 confirmed cases}

212

213

214 (with approximately 10 cases) soon after the beginning until last week of February 2020 and

215

216

217

218

Further, the model was also validated using the projection at global scale. As shown in Table 1, the projections of the confirmed cases are very close to actual value with slight over estimation and the increasing trend is captured well. As mentioned earlier, more data is required to validate the global scale long term projection of model. However, the long-term projection of deaths estimated using these model projections are very close to the projection reported by IHME for the countries such as United States of America (USA) and United Kingdom (UK) [23].

Table 1. Global scale estimates of confirmed cases for validation period

\begin{tabular}{lll}
\hline Date & Projected & Actual \\
\hline March 31, 2020 & 869,406 & 857,487 \\
April 1, 2020 & 957,136 & 932,605 \\
April 2, 2020 & $1,045,551$ & $1,013,320$ \\
April 3, 2020 & $1,134,644$ & $1,095,917$ \\
April 4, 2020 & $1,224,412$ & $1,197,405$ \\
April 5, 2020 & $1,314,850$ & $1,272,115$ \\
April 6, 2020 & $1,405,953$ & $1,345,101$ \\
April 7, 2020 & $1,497,716$ & $1,426,096$ \\
April 8, 2020 & $1,590,135$ & $1,511,104$ \\
April 9,2020 & $1,683,203$ & $1,595,350$ \\
\hline
\end{tabular}

We observed two main behavioural changes in the number of confirmed cases curves (Fig 3). (i) plateau-peak shift: number of confirmed cases in the USA, Australia, and Italy has plateaued increased to peak thereafter. A possible reason could be an inflow of passengers soon after the Chinese New Year [24]. (ii) cross-over during March 2020: though the number of confirmed cases around end of February 2020 (approximately 10 cases) was almost similar for the USA, Australia, Italy, and Iran, Australia's number of confirmed cases were less when compared with 
medRxiv preprint doi: https://doi.org/10.1101/2020.04.17.20069500; this version posted April 22, 2020. The copyright holder for this preprint (which was not certified by peer review) is the author/funder, who has granted medRxiv a license to display the preprint in perpetuity. It is made available under a CC-BY-NC-ND 4.0 International license .

the USA, Italy, and Iran during March 2020. The USA's number of confirmed cases, though lesser than Italy and Iran during the first three weeks of March 2020, has surpassed the cases of Italy and Iran during the end of third week of March 2020 and stayed at peak thereafter. The possible explanation for this behaviour could be attributed to the difference in intervention measures imposed in the respective countries. However, it is important to note that, testing capacity might be one of the keys which dictate the success of non-medical measures such as social-distancing and lockdown to contain the virus [25].

Note that due to the limited observed data for fitting the model, the error in the future projection is expected to be high and increases with time. Thus, the projection was made till June 30, 2020 (three months from March 30, 2020). Along with the estimate of probability, the shape, scale and location parameters of GP distribution were used to project the confirmed cases for the future period. Fig 3 shows the estimate of the number of confirmed cases for the present and future (up to June 30, 2020) for the most affected country of each continent. In Chile and South Africa, during the first week of March 2020, fewer (i.e. around 10 cases) confirmed cases were reported; then an exponential increase was clearly seen during the subsequent weeks. Although number of daily confirmed cases show randomness, the varying pattern across different countries were similar.

As of June 30, 2020, the numbers of the confirmed cases for Italy, Iran, Australia, South Africa and Chile would reach around 1,281,708, 479,531, 76,795, 23,281, and 44,041 respectively. The number of the confirmed cases for the USA would likely to be at least more than one million (highest among all the countries) in the early May 2020, though the initial progression of the 
medRxiv preprint doi: https://doi.org/10.1101/2020.04.17.20069500; this version posted April 22, 2020. The copyright holder for this preprint (which was not certified by peer review) is the author/funder, who has granted medRxiv a license to display the preprint in perpetuity.

It is made available under a CC-BY-NC-ND 4.0 International license .

242 number infected was much lower than other highly affected countries such as Italy and Iran.

243 Similar behaviour in the number of projected confirmed cases was observed for the other less

244 affected countries such as India (refer S3 Fig), however, with less magnitude mainly because of

245 delay in onset of disease spread (early March 2020) and reporting of cases. Majority of the

246 countries (mostly developing and under-developed) at the onset of surging increase in COVID-

24719 spread would neither be equipped with testing facilities nor have the medical infrastructure to

248 tackle the crisis [26]. Therefore, the availability of more data in the forthcoming days would help

249 in producing a more reliable projection of the confirmed cases in the future.

250 S3 Fig: Projection of confirmed cases for the countries with delayed onset of COVID-19

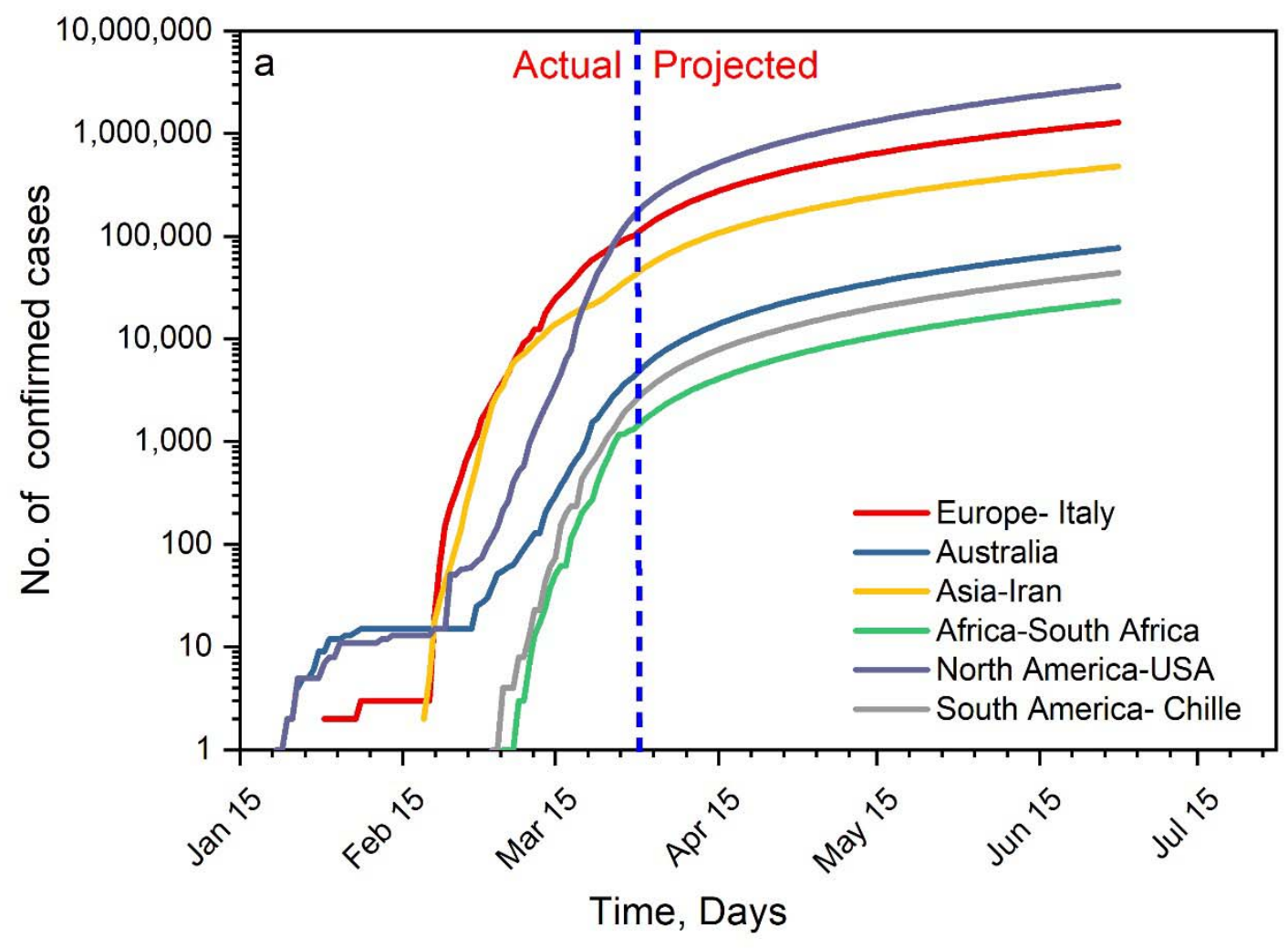


medRxiv preprint doi: https://doi.org/10.1101/2020.04.17.20069500; this version posted April 22, 2020. The copyright holder for this preprint (which was not certified by peer review) is the author/funder, who has granted medRxiv a license to display the preprint in perpetuity.

It is made available under a CC-BY-NC-ND 4.0 International license .

253 Fig 3. Actual and projected trend of cumulative increase of confirmed cases for the selected 254 countries

255

Note that these projections did not explicitly include the effect of the actual stringent control measures (eg. social distancing, travel bans, isolation/quarantine, lockdown) adopted in the various countries at local/regional and national level. However these projections might vary and the number of actual confirmed cases could be less if all the countries apply inter and intra circuit breaking measures (control measures) to reduce the COVID-19 spread. From the projection across the world on June 30, 2020 as illustrated in Fig. 4, 17 thousand (17k) to 3000 thousand (3000k) number of confirmed cases were observed across different countries since January 22, 2020. The maximum number of confirmed cases between 1522k and 2906k were observed in the USA and Spain. Following that Italy and Germany are likely to have more than 1 million confirmed cases.

Globally the total number of confirmed cases would reach 11.4 million by the end of June 2020. Several countries will exceed one million COVID-19 infections within the next two months. For example, USA with the highest number of confirmed cases globally will be the first to reach the one million count in the first week of May, followed by Spain and Italy in the first week of June

271 2020. We also estimated that Germany and France will also exceed a million cases in the middle

272 and end of June respectively. Countries like Iran, UK, Chile and Portugal are also identified to be 273 at high risk since confirmed cases in these countries will exceed half a million by the end of June 2742020. 
medRxiv preprint doi: https://doi.org/10.1101/2020.04.17.20069500; this version posted April 22, 2020. The copyright holder for this preprint (which was not certified by peer review) is the author/funder, who has granted medRxiv a license to display the preprint in perpetuity.

It is made available under a CC-BY-NC-ND 4.0 International license .

276 The current number of the confirmed cases in India is still in the range of few thousands and the

277 future projection is estimated to be around 28,028, which is considerably lesser than the USA

278 and the UK. However currently in India, stringent measures such as 42 days nation-wide

279 lockdown has been imposed to control and stabilize the communal spread in order to prevent

280 from becoming a global hotspot of COVID-19. It is difficult to project realistic estimates for

281 countries like India and Indonesia due to lack of sufficient data which is attributed to the delay in

282 onset of COVID-19 (first week of March 2020). However, upon getting more data with time, our

283 model could be used to project more realistic values.

284

285 In other countries including Japan and South Korea that were severely affected but imposed 286 many preventive measures, would likely to have $23 \mathrm{k}$ and $118 \mathrm{k}$ confirmed cases respectively.

287 However, the number of confirmed cases might still be reduced depending on the effectiveness 288 of the preventive measures. Please refer S4 Table for the country-wise estimates of projected 289 confirmed cases.

290 S4 Table: Country wise estimates of projected confirmed cases

291

292 


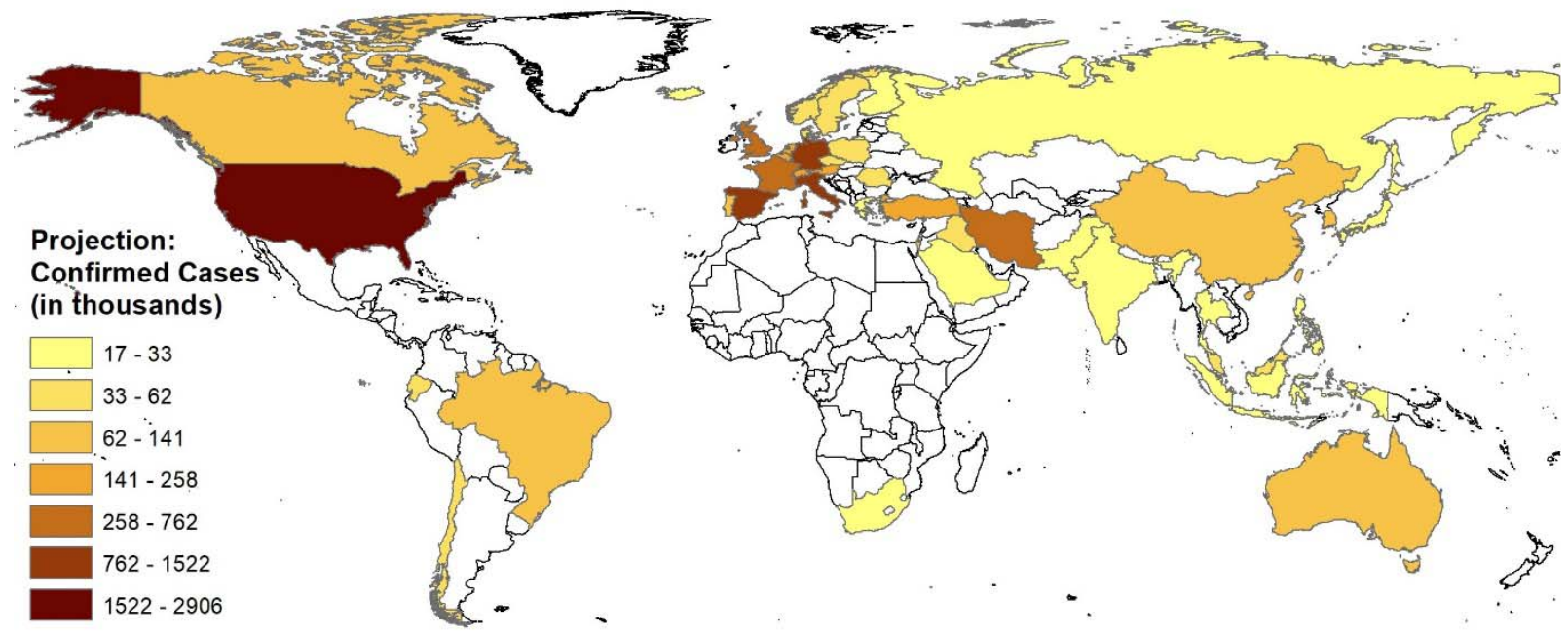

Fig 4. Number of confirmed cases as on June 30, 2020

The rate of increase in the projected confirmed cases were estimated at the end of each months

297 (i.e. April, May and June 2020) including the actual confirmed case (March). This daily rate of 298 confirmed cases was computed from estimating the difference between the cumulative confirmed cases at each month interval and dividing by the total number of days (one month in this case) using the projection of 42 countries. The rate of increase falling in the box (i.e. 25 to 75 percentiles) indicates that in several countries, the impact would be less as the number of confirmed cases per day ranges between few thousand for the projection period varying from April 2020 to June 2020. However, a very high rate of increase in confirmed cases were found in USA, Spain, Italy and Germany followed by France, Iran and UK. 


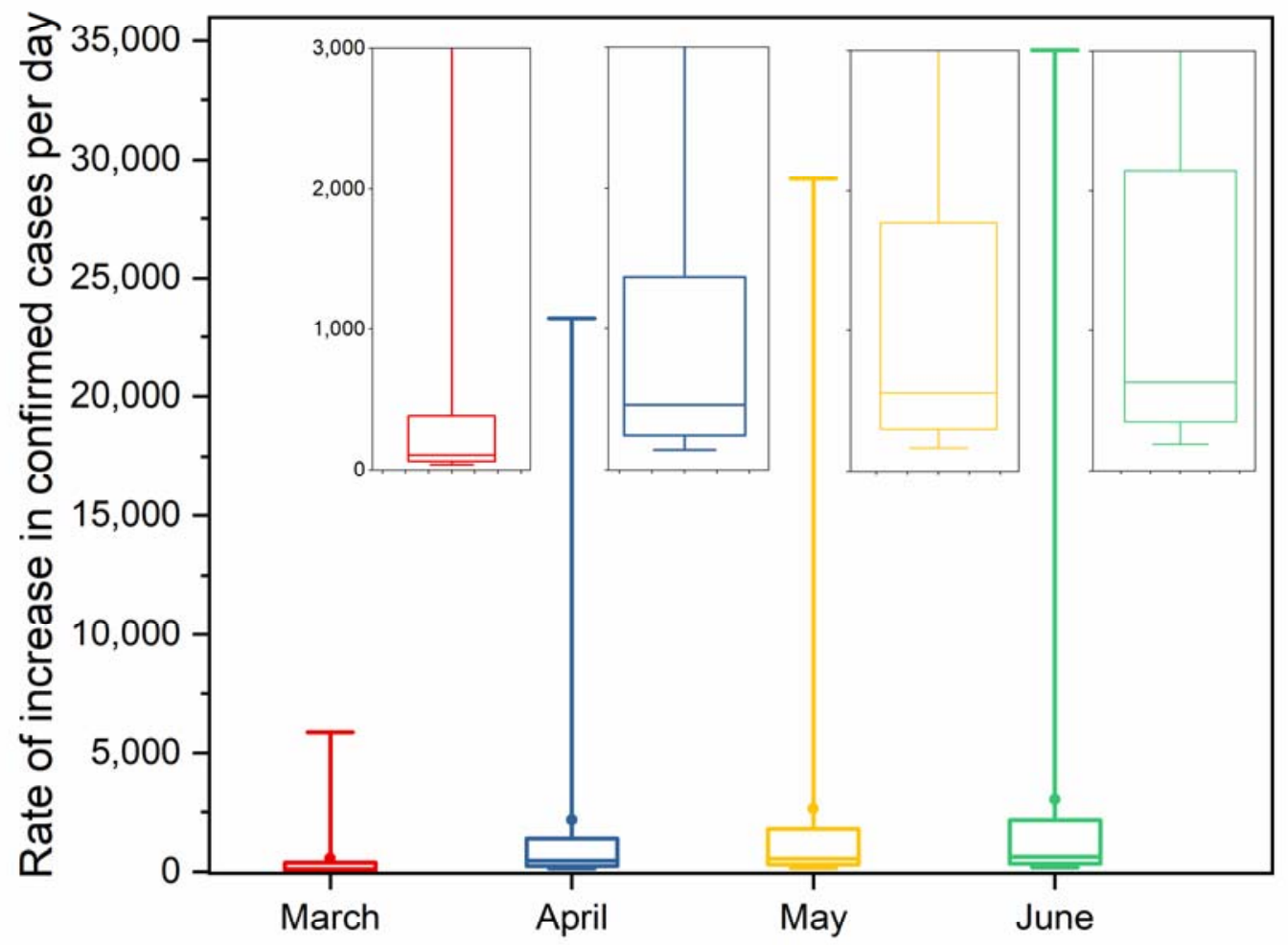

Fig 5. Rate of increase in confirmed cases per day (box plot illustrates variation in the rate from the data of 42 countries)

Besides the projection of confirmed cases, we also estimated the likely number of deaths. CFR is deaths) is not constant and changes with the context (e.g., it can vary with time, age and the

314 of deaths $[4,27,28,29]$. 
medRxiv preprint doi: https://doi.org/10.1101/2020.04.17.20069500; this version posted April 22, 2020. The copyright holder for this preprint (which was not certified by peer review) is the author/funder, who has granted medRxiv a license to display the preprint in perpetuity. It is made available under a CC-BY-NC-ND 4.0 International license .

316 We estimated the average value of the CFR for the selected 42 countries (from March 15, 2020

317 to March 30, 2020) and found the CFR values as 9\%, 8\%, 7\%, 6\%, 5\% and 2\% for the countries

318 Italy, Indonesia, Iran, Spain, UK, France and USA respectively. Based on these CFR estimates

319 along with the model projection for the confirmed cases (Fig 6), we estimated the likely number

320 of deaths on June 30, 2020 and found the number of deaths to be highest in Italy $(115,354)$ and

321 Spain $(91,340)$. The number of deaths in countries such as USA, Iran, France and UK are also

322 likely to be high with $58,110,33,567,30,490$ and 20,116 deaths respectively by the end of June

323 2020. Refer S5 Table5 for the estimated number of deaths of other countries having CFR greater

324 than 1 percent. Our estimate especially for USA $(82,638$ deaths by the end of July 2020) is very

325 close with the number of deaths projected by the IHME health service utilization forecasting

326 team (81,114 deaths) [12].

327 S5 Table: Estimated deaths for selected countries based on the projection of confirmed

328 cases and average CFR value higher than $1 \%$ on June 30, 2020 
medRxiv preprint doi: https://doi.org/10.1101/2020.04.17.20069500; this version posted April 22, 2020. The copyright holder for this preprint (which was not certified by peer review) is the author/funder, who has granted medRxiv a license to display the preprint in perpetuity.

It is made available under a CC-BY-NC-ND 4.0 International license .

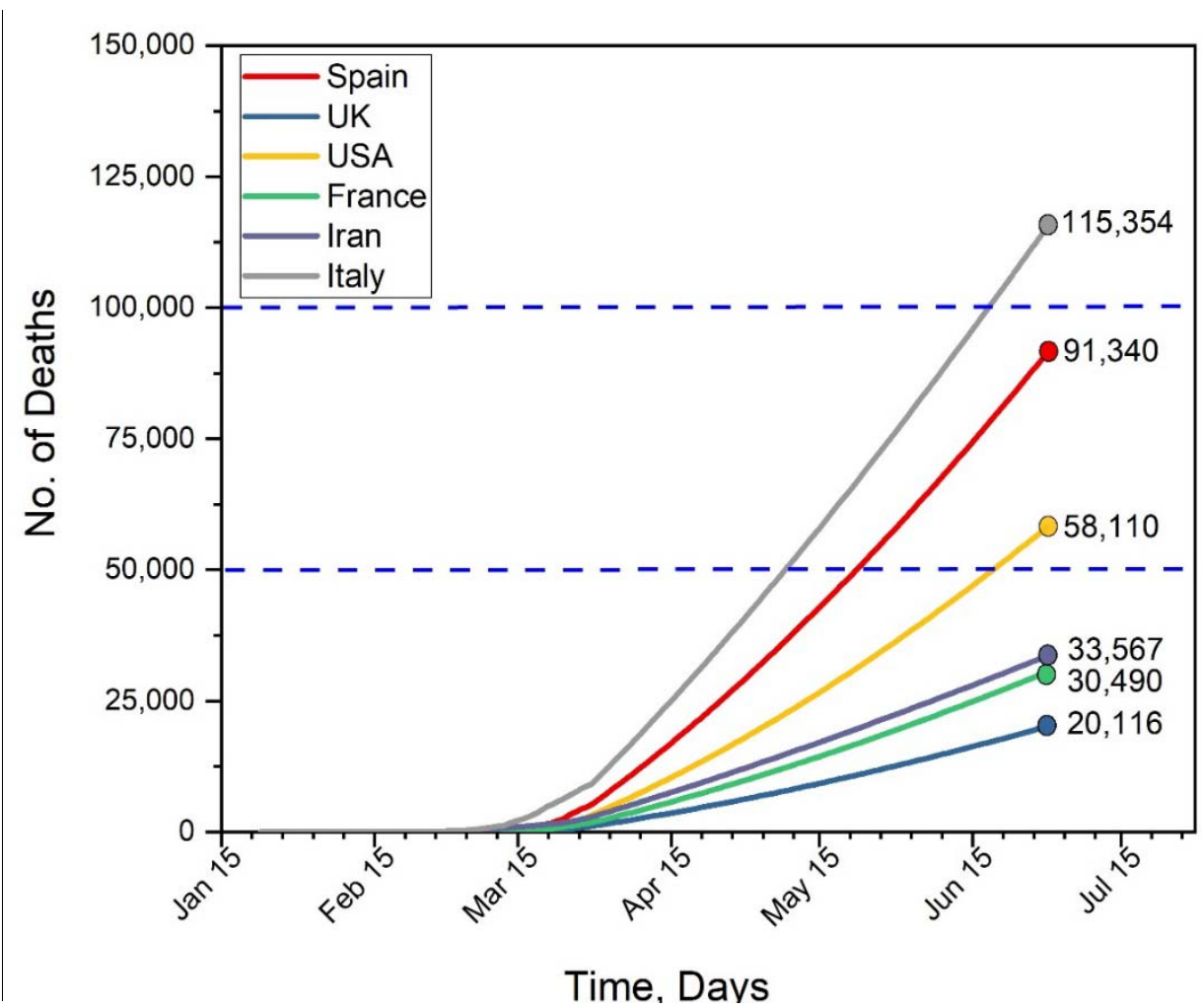

Fig 6. The estimated deaths in selected countries based the results of CFR and projection of cases

Effective lag length is a key variable to estimate the fold increase due to delay in reporting. As days respectively to analyse the impact of delay on number of confirmed cases. Fig 7 is plotted between the number of days delayed and the number of folds increase in the confirmed cases for the selected countries across the world. The mean estimate of fold increase was calculated for each day lag (Fig 7). It is well known as illustrated in Fig 7 that increasing the number of days delay elevates the magnitude of fold increase. The fold increase of 16 and 10 would reach for the 
medRxiv preprint doi: https://doi.org/10.1101/2020.04.17.20069500; this version posted April 22, 2020. The copyright holder for this preprint (which was not certified by peer review) is the author/funder, who has granted medRxiv a license to display the preprint in perpetuity.

It is made available under a CC-BY-NC-ND 4.0 International license.

delay of 7 days in the context of extreme scenario as currently Italy and USA respectively are facing (Fig 7a). In specific, a steep increase was found when the lag length (i.e. delay in reporting) is more than 5 days. Therefore, it is to be noted that sooner the case is identified and reported, better the preventive measures could be ensured without much communal spread [30]. Further, we noticed that although USA is experiencing high surge in confirmed cases, the fold increase for even 1-week delay was considerably less compared to other countries. Perhaps this observation is likely to change as more data will be available. This is a positive point that USA can manage the situation if adequate preventive measures are in place. Overall, it was observed that many of the European countries exhibited similar results. As shown in Fig 7b, though the magnitude of fold increase seems comparatively low in less affected countries, it might increase when the number of confirmed cases increases. Therefore, this is a right time for them to enforce preventive measures to safeguard people from COVID-19.
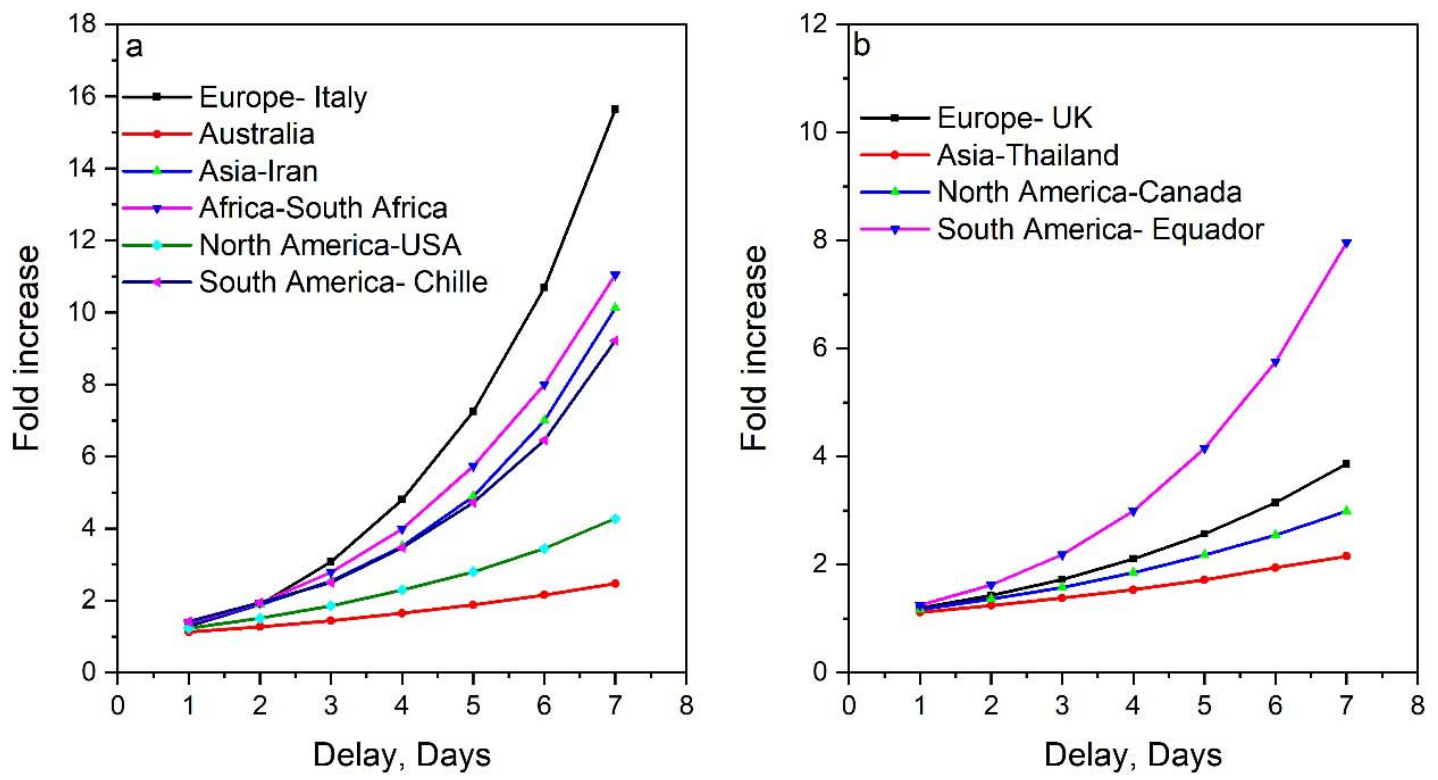
medRxiv preprint doi: https://doi.org/10.1101/2020.04.17.20069500; this version posted April 22, 2020. The copyright holder for this preprint (which was not certified by peer review) is the author/funder, who has granted medRxiv a license to display the preprint in perpetuity.

It is made available under a CC-BY-NC-ND 4.0 International license .

Fig 7. Fold increase in number of confirmed cases for different lag length a) severely

affected b) less affected

\section{Assumptions, limitations, and quantification of uncertainty}

362 The uncertainties associated with the epidemic modeling studies are due to various reasons such assumed or estimated or adopted from previous modeling studies (assumption of incubation period and reproduction number) $[32,33]$ (iii) assumptions or limitations of the model being used. For example, the SEIR model assumes all the population is susceptible to infection. Dynamics transmission model's assumption that symptomatic individuals are more (50\%) susceptible to infection than asymptomatic individuals [32]. Assumptions while conceptualizing the non-pharmaceutical interventions such as duration of stay at home during isolation, percent contact reduction in workplaces, impact of non-pharmaceutical interventions are constant with

371 time and same across all countries etc. [32].

As mentioned earlier, the uncertainty in the projected confirmed cases were quantified only based on the $R_{d}$, and the fold increase estimated from each data point for a fixed lag length will 375 have inherent variability (Fig. 8). This is mainly because the data is highly random and during 376 the initial phase of pandemic the effect of delay will be less and gradually increase with time. 377 Although the mean estimate as reported in the previous section is a good choice to quantify the 378 delay effect in the projection, ignoring the uncertainty might under predict the likely estimate of 379 future period. Therefore, we estimated $95 \%$ confidence interval from the estimate of fold increase. From the lag length period of 1 to 7 days, we considered on an average of 3- and 5-days 
medRxiv preprint doi: https://doi.org/10.1101/2020.04.17.20069500; this version posted April 22, 2020. The copyright holder for this preprint (which was not certified by peer review) is the author/funder, who has granted medRxiv a license to display the preprint in perpetuity.

It is made available under a CC-BY-NC-ND 4.0 International license .

381 lag based on the delay in reporting to estimate the range of variation in the projection especially

382 in the confirmed cases. We chose Australia, randomly, to illustrate the impact of uncertainty in

383 the projection (Fig 8). It is evident from Fig 8 that the median projected confirmed cases and

384 uncertainty increases with time. For example, the median projected confirmed cases increased

385 from 6,958 on March 302020 to 108,447 on 30 June 2020 for $R_{d}$ of 3 days. Similarly, the width

386 of uncertainty band for projected confirmed cases on 31 March 2020 was 6,596-7,593 (upper

387 bound - lower bound) while it has increased to 102,816-118,357 on June 30 2020. Refer Table 2

388 for median and CI intervals for selected seven countries.

390 It is expected that the unbiased estimate of uncertainty band will have the median estimate closer

391 to the mid-portion of the band. In other words, any deviation from this mid-portion of the band

392 represents the bias in the uncertainty estimate. However, we found the median falling towards

393 the upper bound in most of the countries mainly due to the drastic increase in number of cases

394 with during the critical period. As shown earlier in Fig 7, the delay in reporting increases the

395 fold-increase in confirmed cases which in turn will significantly increase the projection range as

396 well as the uncertainty (Table 2). 
medRxiv preprint doi: https://doi.org/10.1101/2020.04.17.20069500; this version posted April 22, 2020. The copyright holder for this preprint (which was not certified by peer review) is the author/funder, who has granted medRxiv a license to display the preprint in perpetuity.

It is made available under a CC-BY-NC-ND 4.0 International license .
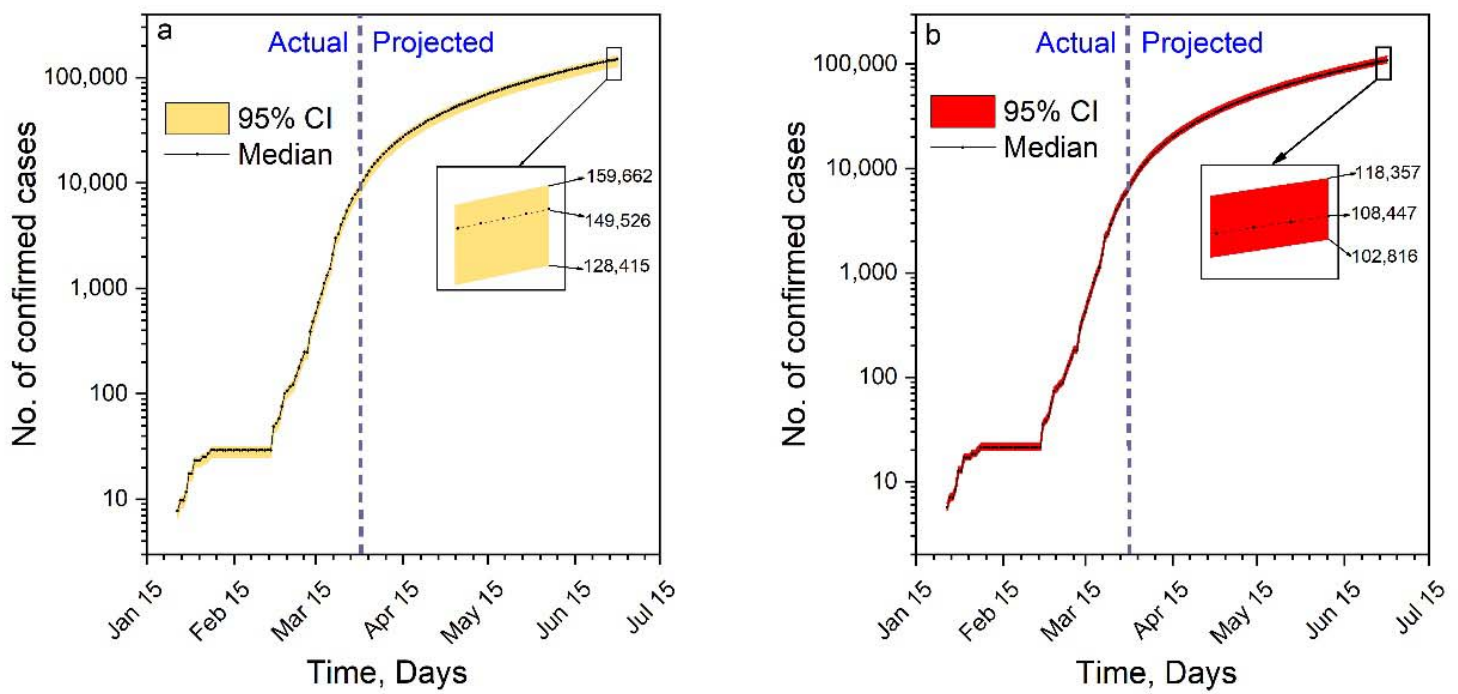

Fig 8. Actual and projected confirmed cases with uncertainty band for a) 5 days delay and b) 3 days delay for Australia

401

Table 2. Projection of confirmed cases with uncertainty in Reporting delay of 3 and 5 days respectively for selected countries

\begin{tabular}{rllrr}
\hline S.No & Country & Continent & 95\% CI for $\mathrm{R}_{\mathrm{d}}=3$ days & 95\% CI for $\mathrm{R}_{\mathrm{d}}=5$ days \\
\hline 1 & Australia & Australia & $102,816-118,357$ & $128,415-159,662$ \\
2 & Chile & South America & $95,322-124,776$ & $167,684-247,728$ \\
3 & Iran & Asia & $836,231-1,602,385$ & $1,371,580-3,314,668$ \\
4 & Italy & Europe & $1,496,111-6,387,634$ & $2,866,670-15,697,496$ \\
5 & South Africa & Africa & $51,117-78,259$ & $91,763-175,052$ \\
6 & USA & North America & $4,795,011-5,971,468$ & $7,037,335-9,191,516$ \\
\hline
\end{tabular}

402

403

Summary and limitations

404 This study explored the (i) applicability of EVDs in predicting the COVID-19 confirmed cases, and (ii) possible relation between the delay in reporting the cases and the potential increase in the number of infection (number of confirmed cases). The results of the projection indicate that the 
medRxiv preprint doi: https://doi.org/10.1101/2020.04.17.20069500; this version posted April 22, 2020. The copyright holder for this preprint (which was not certified by peer review) is the author/funder, who has granted medRxiv a license to display the preprint in perpetuity.

It is made available under a CC-BY-NC-ND 4.0 International license .

USA would have the highest number of confirmed cases of 2,905,522 (4,795,011-5,971,468 for $\mathrm{R}_{\mathrm{d}}=3$ days) and Iceland to have the minimum number of confirmed cases of 21,166 (2722258,008 for $R_{d}=3$ days) by June 30,2020 . The number of deaths has also been estimated for the 42 countries and found that the deaths to be maximum in Italy (115,354 deaths) followed by Spain $(91,340)$ by June 30, 2020.

It may be noted that we have not considered any intervention measures (i.e. lockdown, social distancing, school closures etc.,) in the model rather we focused on projecting the actual trend exist in the data, thereby informing the likely increase in number of confirmed cases due to COVID-19 outbreak. As inferred from this study, the reporting delay should be minimized to get more accurate information on the confirmed cases. Therefore, the uncertainty due to delay in reporting should not be ignored in the projection in order to estimate the reliable number of confirmed cases. However, future studies will include other sources of uncertainty such as model, parameter and input for the more realistic projection. The projected confirmed cases are based on the data collected until March 30, 2020. However, we will be updating the model projection once in every two weeks and our results will be posted in twitter handle @Hydroviswa and @ IdhayaI.

\section{Reference}

1. Koo KR, Cook AR, Park M, Sun Y, Sun H, Lim JT. Et al. (2020) Interventions to mitigate early spread of SARS-CoV-2 in Singapore: a modelling study. T. Lan. Infec. Dis. doi: 10.1016/S1473-3099(20)30162-6 
medRxiv preprint doi: https://doi.org/10.1101/2020.04.17.20069500; this version posted April 22, 2020. The copyright holder for this preprint (which was not certified by peer review) is the author/funder, who has granted medRxiv a license to display the preprint in perpetuity. It is made available under a CC-BY-NC-ND 4.0 International license .

2. Bolddog P, Tekeli T, Vizi Z, Denes A, Bartha FA, Rost G. (2020) Risk Assessment of Novel Coronavirus COVID-19 Outbreaks Outside China. J. Clin. Med. 9(2)-571. doi: $10.3390 /$ jcm 9020571

3. Data Repository by Johns Hopkins CSSE [Internet] -2019 Novel Coronavirus COVID19. [cited 2020 Apr 03$]$ Available from: https://gisanddata.maps.arcgis.com/apps/opsdashboard/index.html\#/bda7594740fd40299 $423467 \mathrm{~b} 48 \mathrm{e} 9 \mathrm{ecf6}$

4. Roser M, Ritchie H, Ortiz-Ospine E. (2020) Coronavirus Disease (COVID-19) Statistics and research. Oxford Martin School, Published online at OurWorldInData.org. [Cited 2020 April 03]. Available from: https://ourworldindata.org/coronavirus

5. Stehlé J, Voirin N, Barrat A, Cattuto C, Colizza V, Isella L. et al. (2011) Simulation of an SEIR infectious disease model on the dynamic contact network of conference attendees. BMC Med. 9-87. doi: 10.1186/1741-7015-9-87.

6. Tuite AR, Fisman DN. (2020) Reporting, Epidemic Growth, and Reproduction Numbers for the 2019 Novel Coronavirus (2019-nCoV) Epidemic. Annals of Internal Medicine. doi: 10.7326/M20-0358.

7. Hu Z, Ge Q, Li S, Jin L, Xiong M. (2020) Artificial Inteligence Forecasting of Covid-19 in China. q-bio.OT. Avaialble From: https://arxiv.org/abs/2002.07112

8. Wu JT, Leung K, Leung GM. (2020) Nowcasting and forecasting the potential domestic and international spread of the 2019-nCoV outbreak originating in Wuhan, China: a modelling study. The Lancet. 395(10225):689-8. doi: 10.1016/S0140-6736(20)30260-9. 
medRxiv preprint doi: https://doi.org/10.1101/2020.04.17.20069500; this version posted April 22, 2020. The copyright holder for this preprint (which was not certified by peer review) is the author/funder, who has granted medRxiv a license to display the preprint in perpetuity. It is made available under a CC-BY-NC-ND 4.0 International license .

9. Kucharski A, Russell TW, Diamond C, Liu Y, Edmunds J, Funk S. (2020) Early dynamics of transmission and control of COVID-19: A mathematical modelling study. T. Lan. Infec. Dis. doi: 10.1016/S1473-3099(20)30144-4

10. Sen M, Peng Z, Xiao Y, Zhang L. (2020) Modelling the epidemic trend of the 2019 novel coronavirus outbreak in China. bioRxiv [Preprint]. 2020 [Cited 2020 April 5]. Available from: https://www.biorxiv.org/content/10.1101/2020.01.23.916726v1.article-info. doi $10.1101 / 2020.01 .23 .916726$

11. Zhao S, Musa SS, Lin Q, Ran J, Yang G, Wang W. (2020) Estimating the unreported number of Novel Coronavirus (2019-nCoV) cases in China in the first half of January 2020: A data-driven modelling analysis of the early outbreak. J. Clin. Med. 2020, 9(2), 388. doi: $10.3390 /$ jcm 9020388

12. Thomas M, Lemaitre M, Wilson ML, Viboud C. (2016) Applications of Extreme Value Theory in Public Health. PLoS ONE 11(7): e0159312. doi: 10.1371/journal.pone.0159312

13. Tariq A, Lee Y, Roosa K, Blumberg S. (2020) Real-time monitoring the transmission potential of COVID-19 in Singapore, February 2020. MedRxiv [Preprint]. 2020 [Cited 2020 April $5]$. Available from: https://www.medrxiv.org/content/10.1101/2020.02.21.20026435v6.article-info. doi: $10.1101 / 2020.02 .21 .20026435$

14. Kraemer MUG, Yang CH, Gutierrez B, Wu CH. (2020) The effect of human mobility and control measures on the COVID-19 epidemic in China. Science. doi: 10.1126/science.abb4218 
medRxiv preprint doi: https://doi.org/10.1101/2020.04.17.20069500; this version posted April 22, 2020. The copyright holder for this preprint (which was not certified by peer review) is the author/funder, who has granted medRxiv a license to display the preprint in perpetuity. It is made available under a CC-BY-NC-ND 4.0 International license .

15. Azman AS, Luquero F. (2020) From China: hope and lessons for COVID-19 control. T. Lan. Infec. Dis. doi: 10.1016/S1473-3099(20)30264-4

16. Zhao S, Lin Q, Ran J, Musa SS. (2020) Preliminary estimation of the basic reproduction number of novel coronavirus (2019-nCoV) in China, from 2019 to 2020: A data-driven analysis in the early phase of the outbreak. Int. J. Infec. Dis. doi: 10.1016/j.ijid.2020.01.050

17. Zhi Z. (2020) The epidemiological characteristics of an outbreak of 2019 novel coronavirus diseases (COVID-19) in China. Chinese Journal of Epidemiology [Preprint]. 2020 [Cited 2020 April 07]. doi: 10.3760/cma.j.issn.0254-6450.2020.02.003

18. Chiu Y, Chebana F, Abdous. (2018) Mortality and morbidity peaks modeling: An extreme value theory approach. Statistical Methods in Medical Research. doi: $10.1177 / 0962280216662494$

19. Northrop PJ. (2004) Likelihood-based approaches to flood frequency estimation. Journal of Hydrology. doi: 10.1016/j.jhydrol.2003.12.031

20. Sen S, He J, Kasiviswanathan K.S. (2020) Uncertainty quantification using the particle filter for non-stationary hydrological frequency analysis. Journal of Hydrology. doi: 10.1016/j.jhydrol.2020.124666

21. Hosking JRM. (1990) L-Moments: Analysis and Estimation of Distributions Using Linear Combinations of Order Statistics. Journal of Royal Statistical Society. Series B (Methodological). From: https://www.jstor.org/stable/2345653

22. Nicoletta Lanse. (2020) Even if you test negative for COVID-19, assume you have it, experts say. Live Science. 2020 April 3 [Cited 2020 April 9 ] Available from: https://www.livescience.com/covid19-coronavirus-tests-false-negatives.html 
medRxiv preprint doi: https://doi.org/10.1101/2020.04.17.20069500; this version posted April 22, 2020. The copyright holder for this preprint (which was not certified by peer review) is the author/funder, who has granted medRxiv a license to display the preprint in perpetuity.

It is made available under a CC-BY-NC-ND 4.0 International license .

497

498

499

500

501

502

503

504

505

506

507

508

509

510

511

512

513

514

515

516

23. Murray JL. (2020) Forecasting COVID-19 impact on hospital bed-days, ICU-days, ventilator days and deaths by US state in the next 4 months. medRxiv [Preprint]. 2020 [Cited

2020

April

7]

Available

from:

https://www.medrxiv.org/content/10.1101/2020.03.27.20043752v1.

doi:

$$
10.1101 / 2020.03 .27 .20043752
$$

24. Eder S, Fountain H, Keller MH, Xiao M. 43,000 People Have Travelled From China to U.S. Since Coronavirus Surfaced. The New York Times. 2020 April 4 [Cited 2020 April 9]. Available From: https://www.nytimes.com/2020/04/04/us/coronavirus-china-travelrestrictions.html

25. Colbourn T. (2020) COVID-19: extending or relaxing distancing control measures. T. LANCET Pub. Health. doi: 10.1016/ S2468-2667(20)30072-4

26. Cavallo JJ, Donoho DA, Forman HP. (2020) Hospital Capacity and Operations in the Coronavirus Disease 2019 (COVID19) Pandemic—Planning for the Nth Patient. Insights. 2020 March 17 [Cited 2020 April 10]. Available from: https://jamanetwork.com/channels/health-forum/fullarticle/2763353

27. Wong JY, Kelly H, Dennis KM, Wu JT. (2013). Case fatality risk of influenza A $\begin{array}{llll}\text { (H1N1pdm09): } & \text { a } & \text { systematic } & \text { review. }\end{array}$ doi: 10.1097/EDE.0b013e3182a67448

28. Lipsitch M, Donnelly CA, Fraser C, Blake IM, Cori A, et al. (2015) Potential Biases in Estimating Absolute and Relative Case-Fatality Risks during Outbreaks. PLOS Neglected Tropical Diseases 9(7): e0003846. doi: 10.1371/journal.pntd.0003846 
medRxiv preprint doi: https://doi.org/10.1101/2020.04.17.20069500; this version posted April 22, 2020. The copyright holder for this preprint (which was not certified by peer review) is the author/funder, who has granted medRxiv a license to display the preprint in perpetuity.

It is made available under a CC-BY-NC-ND 4.0 International license .

29. Kobayashi T, Jung SM, Linton NM, Kinoshita R. (2020). Communicating the Risk of Death from Novel Coronavirus Disease (COVID-19). J. Clin. Med. doi: $10.3390 /$ jcm 9020580

30. Shear MD, Goodnough A, Kaplan S, Fink S. (2020) The lost month: How a failure to test blinded the US to COVID-19. The Economic Times. 2020 March 30 [Cited 2020 April 5]. Available from: https://economictimes.indiatimes.com/news/international/worldnews/the-lost-month-how-a-failure-to-test-blinded-the-us-to-covid19/articleshow/74876897.cms

31. Jennifer AG, Lauren AM, Alison PG, Jeffrey PT. (2020) Probabilistic uncertainty analysis of epidemiological modeling to guide public health intervention policy. Epidemics. doi: 10.1016/j.epidem.2013.11.002

32. Flaxman S, Mishra S, Gandy A. (2020) Estimating the number of infections and the impact of non-pharmaceutical interventions on COVID-19 in 11 European countries. Imperial College London. doi: 10.25561/77731

33. Özmen Ö, Nutaro JJ, Pullum LL, Ramanathan A. (2016) Analyzing the impact of modeling choices and assumptions in compartmental epidemiological models. Simulation. doi: 10.1177/0037549716640877.

\section{Ethics approval and consent to participate}

The ethical approval or individual consent was not applicable

\section{Availability of data and materials}


medRxiv preprint doi: https://doi.org/10.1101/2020.04.17.20069500; this version posted April 22, 2020. The copyright holder for this preprint (which was not certified by peer review) is the author/funder, who has granted medRxiv a license to display the preprint in perpetuity.

It is made available under a CC-BY-NC-ND 4.0 International license .

538 The data were retrieved by the Center for Systems Science and Engineering(CSSE) at Johns

539 Hopkins University: https://github.com/CSSEGISandData/COVID-19 [accessed on March 31, $5402020]$.

542 Funding

543 The authors KSK and II would like to thank Indian Institute of Technology Roorkee for

544 supporting this research financially.

545

546 Competing Interests

547 The authors have declared that no competing interests exist.

548

549 Acknowledgement

550 Authors would like to thank Editor and anonymous reviewers for reviewing the paper. All 551 authors would like to sincerely acknowledge their family members for supporting and 552 encouraging to carry out the research work during this critical lockdown period.

\section{Authors Contribution}

555 Conceived and designed the experiments: KSK. Performed the experiments: MA, KSK.

556 Analyzed the data: KSK, MA, II, BS. Contributed reagents/materials/analysis tools: MA, MB.

557 Wrote the paper: KSK, II, MA, BS. Interpretation of results: KSK, II, MA, JH, MB. Developed

558 the codes: JH, KSK, MA. 
medRxiv preprint doi: https://doi.org/10.1101/2020.04.17.20069500; this version posted April 22, 2020. The copyright holder for this preprint (which was not certified by peer review) is the author/funder, who has granted medRxiv a license to display the preprint in perpetuity.

\author{
It is made available under a CC-BY-NC-ND 4.0 International license.
}

